\title{
Minimality and Onset Conditions Interact with Vowel Harmony in Fungwa
}

\author{
Samuel Akinbo \\ University of British Columbia
}

\section{Introduction}

This paper explores how the domain of vowel harmony can be affected by conditions involving minimality and the requirement for an onset. In this work, I augment the argument that onset, minimality and phonological conditions refer to a prosodic word as the domain of operation. This argument is supported with data on vowel harmony in Fungwa (Kainji, Benue-Congo). The problem in Fungwa is that a root vowel can trigger harmony which targets the vowel of a CV-prefix but does not target the vowel of a V-prefix.

I argue that vowel harmony, minimality and onset conditions refer to a prosodic constituent as the domain of operation in Fungwa. Consequently, the minimality condition dictates the integration of the onsetful prefix into a prosodic word, but the onset condition excludes the onsetless prefix from the prosodic word, the domain of harmony. The integration of the target into the domain of harmony is based on the analysis of affixation as prosodic integration (Booij, 1996; Peperkamp, 1999). Furthermore, the onset condition on the domain of harmony is based on Downing's (1998) account of onsetless syllables. This argument is in line with the prosodic structure theory that constraints refer to prosodic constituents, in this case, the prosodic word (Selkirk, 1980, 1996; Downing, 1998; Hall, 1999). These prosodic constituents are parts of the Prosodic Hierarchy (Selkirk, 1996:190). The well-formedness of the hierarchy is enforced by the strict layering hypothesis: a given non-terminal unit is composed of one or more units of the immediately lower category.

In section 2, I describe and analyse the basic vowel harmony in Fungwa involving onsetful prefixes. In the analysis, a prosodic word is assumed as the domain of harmony. Section 3 contains a formal account of the basic harmony. Onsetless prefixes are described and analysed in section 4. This analysis of onsetless prefixes involves the interaction between the onset condition and the constraints on harmony. In section 4.2, $\mathrm{I}$ argue a minimality condition triggers the integration of $\mathrm{CV}$ prefixes into the domain of harmony. This prosodic integration also accounts for vowel harmony involving a CV clitic in section 5.

\section{Basic backness harmony: CV prefixes}

CiFungwa or simply Fungwa has about 1000 speakers in Rafi local government, Niger State, Nigeria. The data presented in this work were elicited between 2015 and 2018 in six Fungwa villages. Fungwa has seven oral vowels. The vowels can be grouped into two natural classes, namely [-back] and [+back]. The low vowel [a] is phonologically grouped with [+back] vowels. Fungwa is a tone language. There are two tones in Fungwa: H(igh) [bú] 'you', L(ow) [bù] 'she'. All the data presented in this work are in phonetic transcription.

$$
\begin{aligned}
& \text { Fungwa vowel inventory } \\
& \text { [-back]: i e } \varepsilon \\
& \text { [+back]: u о о a }
\end{aligned}
$$

\footnotetext{
* This research is funded by UBC Arts Graduate Research Awards (GRSA) 12R23797, Endangered Language Development Program (SOAS) SG0406, and an SSHRC insight grant (435-2016-0369) awarded to Douglas Pulleyblank. I thank Yakubu Mohammed and all Fungwa people for sharing their language with me and for assisting me with the translation of Fungwa narratives. For helpful comments and guidance on various aspects of this work, I thank Douglas Pulleyblank, Rose-Marie Déchaine, Gunnar Hansson, Avery Ozburn and the audience at AMP 2018. Any errors of fact or explanation are my own responsibility.
}

(C) 2019 Samuel Akinbo

Proceedings of AMP 2018 
The vowels in Fungwa are implicated in vowel harmony. Vowel harmony in Fungwa involves the feature [ $\alpha$ back]. For example, the vowels of $\mathrm{CV}$ prefixes agree in backness with the root vowel. Consider the nouns with C(lass) 12 singular prefix (2) and C22 plural prefix (3) ${ }^{1}$. It is important to note that the vowels of the CV prefix bear the same tone as the following tone bearing unit (TBU).

$$
\text { C12-root: Front }
$$

C12-root: Back

$\begin{array}{llll}\text { a. bí-gígézè } & \text { 'bone' } & \text { bú-gúlù } & \text { 'bellow' } \\ \text { b. bí-jégè } & \text { 'fish' } & \text { bú-dógù } & \text { 'meat' } \\ \text { c. bí-lépè } & \text { 'skin' } & \text { bú-bá?à } & \text { 'child' }\end{array}$

$$
\text { C22-root: Front }
$$
a. tjí-pipíî்̃
b. t tjì-pèlé
c. t tjí-gétè

'he-goats'
'caps'
'hearts'

C22-root: Back

$\begin{array}{ll}\text { tfù-gùlú } & \text { 'vultures' } \\ \text { tfú-kókójồ } & \text { 'roosters' } \\ \text { tfú-lágù } & \text { 'turning sticks' }\end{array}$

As shown in (2), the C12 singular prefix is [bi] when the root vowel is front, but [bu] when the root vowel is back. Similarly in (3), the C22 plural prefix is [t $\mathrm{i}$ i] when the root vowel is front, but [t $\mathrm{tu}]$ when the root vowel is back. In summary, the prefix vowels consistently assimilate the back feature of the root vowel, rather than vice versa. Harmony where stem/root vowels trigger assimilation targeting prefix vowels is a form of root-controlled harmony (Clements, 1985) or stem-controlled harmony (Baković, 2000, 2003).

\section{Span Theory analysis of Fungwa harmony}

The vowel harmony above can be formally accounted for by assuming a constraint which enforces the back-feature agreement of vowels within a domain which contains the prefix and root. This can be done with any of the OT-based approaches to harmony. Considering this work is not mainly on the formal approach to harmony, I adopt McCarthy's (2004) Span Theory.

Span Theory (McCarthy, 2004) is a theory of local and non-local assimilation. It is a representational alternative to other OT-based theories of harmony, such as SPREAD (Padgett, 1997), ALIGN (McCarthy \& Prince, 1993a), and AGREE (Baković, 2000). In Span Theory, segments in a word are required to be exhaustively parsed into a span for each distinctive feature. Each span of the feature has a head, whose feature value determines the feature of other segments in the span. For this theory, McCarthy proposes four constraint-types. In this work, I will only be mentioning the constraint types in Span Theory that play a role in my analysis of Fungwa vowel harmony.

To account for the backness harmony in Fungwa, I provide the [back] feature formulations of the constraints in (4). These formulations are based on the ATR-specific span constraints in O'Keefe (2007) and Akinlabi (2009). The constraint in (4-a) assigns a violation mark for adjacent [ $\alpha$ back] feature spans of vowels in PWd. In this case, PWd is assumed as the domain of harmony in Fungwa and the constraint in (4-a) operates in PWd. The alternation of the prefix vowel signals the violation of a faithfulness constraint. The faithfulness constraint is formulated as the constraint in (4-b).

(4) [back] specific head span constraints

a. *A-SPAN $(\alpha$ back $)$

No adjacent $[\alpha$ back] spans on vowels in PWd.

b. FTHHDSP $(\alpha$ back $)$

If an input vowel $\mathrm{x}_{\mathrm{I}}$ is $[\alpha \mathrm{back}]$ and it has an output correspondent $\mathrm{x}_{0}$, then $\mathrm{x}_{\mathrm{o}}$ is the head of an [ $\alpha$ back] span.

c. $\operatorname{FAITH}(\alpha \text { back })_{(\mathrm{RT})}$

Let $\alpha$ be an input vowel contained in a root, and $\beta$ the output correspondent of $\alpha$. If $\alpha$ is [ $\gamma$ back], then $\beta$ must be [ $\gamma$ back].

The stem control account of directionality accounts for the direction of harmony in Fungwa. In this approach, the direction of harmony depends on the location of an affix relative to a root (i.e. which one

\footnotetext{
1 The number-marking nominal prefixes in Fungwa are grouped into semantic classes which are comparable to those of Bantu languages (Katamba, 2003). For example, bi-/bu- is a class 12 singular that marks diminutive.
} 
precedes which) (McCarthy \& Prince, 1999; Baković, 2000). According to this account, vowel harmony just happens to go from right to left because there is a prefix. To account for the root vowel triggering harmony on the prefix vowel, I assume the positional faithfulness constraint in (4-c). The constraint in (4-c) is violated when the [back] feature value of a root vowel in the input is changed in the output. In line with Akinlabi (2009) and O'Keefe (2007), this constraint is adopted in place of FaithHeadSpan $(\alpha \mathrm{F})_{(\mathrm{RT})}$. The root vowel heads a span as a result of the combined effect of $\operatorname{FAITH}(\alpha \text { back })_{(\mathrm{RT})}$ and ${ }^{*} \mathrm{~A}-\mathrm{SPAN}(\alpha$ back $)$. Based on this combined effect, if the segments in a span must share a [back] feature, and if the [back] feature value of the root vowel cannot change, it implies that the [back] value of the prefix vowel will change if it is different.

This set of constraints derives the forms in (5) and (6). While a harmonic span is enclosed in parentheses, the head of the Span is underlined. The root is indicated with ' $\sqrt{ }$ '. In (5) and (6), I demonstrate that any assumed [back] feature specification of the prefix vowel is irrelevant by assuming an input affix form opposite that of the root vowel.

\begin{tabular}{|c|c|c|c|c|}
\hline & bi- $\sqrt{ }$ Pô & FAITH $(\alpha \mathrm{bk})_{(\mathrm{rt})}$ & ${ }^{*} \mathrm{~A}-\mathrm{SPAN}(\alpha \mathrm{bk})$ & FTHDSP $(\alpha \mathrm{bk})$ \\
\hline a. & (bí)(?̂ㅇ) & & $* !$ & \\
\hline b. & (bíi)(?êe) & $* !$ & $*$ & $*$ \\
\hline & (bíîê) & $* !$ & & $*$ \\
\hline d. & (bú?ô) & & & * \\
\hline
\end{tabular}

(6)

\begin{tabular}{|c|c|c|c|c|}
\hline & bu- $\sqrt{ }$ gétè & FAITH $(\alpha \mathrm{bk})_{(\mathrm{rt})}$ & ${ }^{*} \mathrm{~A}-\mathrm{SPAN}(\alpha \mathrm{bk})$ & FTHDSP $(\alpha \mathrm{bk})$ \\
\hline a. & (bú)(géstè) & & $* !$ & $*$ \\
\hline b. & (bú)(gátà) & $* !$ & * & $* *$ \\
\hline & (búgátà) & $* ! *$ & & $* *$ \\
\hline d. 嗐 & (bígétì) & & & $* *$ \\
\hline
\end{tabular}

With the completely harmonic forms in (5) and (6), there can only be one harmonic span. This is clearly demonstrated with the ruling out of the candidates in (5-a) and (6-a) for *A-SPAN $(\alpha$ back $)$ violations. The winning candidates in (5-d) and (6-d) having a single feature span at the expense of faithfulness to [back] feature in the prefix vowels, which shows having a single span outranks faithfulness to the back feature value of a prefix vowel. The [back] feature of the prefix vowel changing rather than the [back] feature of the root vowel shows faithfulness to the [back] feature of a root vowel outranks faithfulness to the [back] feature of a prefix vowel. Overall, *A-SPAN $(\alpha$ back $)$ ruled out adjacent [back] spans, and FAITH $(\alpha \text { back })_{(\mathrm{RT})}$ ensures the feature [back] of a root vowel is not changed.

\section{Onsetless prefixes}

Unlike the CV prefixes, Onsetless prefixes do not harmonise with the following root vowel. Consider the C20 singular prefix in (7) and the C8 plural prefix in (8).

$$
\text { C20-root: Front }
$$
a. i-pihi
b. í-pèlé
c. i-héhù
d. í-dèní

\section{C8-root: Front}
a. á-jísò
b. á-fílò
c. á-rèké
d. á-pélà

C20-root: Back

$\begin{array}{ll}\text { i-túmã̀ } & \begin{array}{l}\text { 'farming' } \\ \text { í-dógù }\end{array} \\ \text { í-kấgù } & \begin{array}{l}\text { 'mout' } \\ \text { í-lápà }\end{array} \\ \text { C8-root: Back' } \\ \text { á-fúkù } & \\ \text { á-búbà } & \text { 'lungs' } \\ \text { á-wốdó } & \text { 'leaves' } \\ \text { á-dàdá } & \text { 'mothers' } \\ \text { 'hard palates' }\end{array}$

As shown in (7), the C20 singular prefix /í/- is invariant regardless of the [back] feature value of the following root vowel. Similarly, the C8 plural prefix /á/- in (8) is also invariant.

Disharmony of the onsetless prefixes is interesting in various ways. Comparatively, the onsetless prefixes 
occur in the same environment as the onsetful prefixes and they both perform number-marking functions. The vowel of the $\mathrm{C} 20$ singular prefix is comparable to the vowels of the onsetful prefixes. However, the constraint set utilised in the analysis of the onsetful prefixes fails to predict the correct output (which is indicated with ' $\odot$ ') as the optimal candidate for an onsetless prefix. This is illustrated in (9).

\begin{tabular}{|c|c|c|c|c|}
\hline & 1 ídógù & FAITH $(\alpha b k)_{(\mathrm{rt})}$ & *A-SPAN $(\alpha b k)$ & FTHDSP $(\alpha \mathrm{bk})$ \\
\hline a. $:-$ & (1́)(dógù) & & $* !$ & * \\
\hline b. & (1̂)(dégì) & $* ! *$ & * & ** \\
\hline c. & (ídégì) & $* ! *$ & & ** \\
\hline d. & (údógù) & & & ** \\
\hline
\end{tabular}

The invariance of onsetless prefixes cannot be attributed to the syntax since the onsetless prefixes occur in the same syntactic environment as the onsetful ones and perform the same syntactic function. However, the phonological asymmetry between the CV and $\mathrm{V}$ prefixes in terms of the presence vs. absence of an onset points to a prosodic condition on the domain of harmony. To understand this condition, it is important to refer to the phonological structure of words in Fungwa.

4.1 Prosodic misalignment of onsetless prefixes In many languages, onsetless syllables are excluded from the domain of certain phonological processes. For example, in Yorùbá, onsetless syllables do not bear H tone (Akinlabi, 1985; Pulleyblank, 1986; Ola, 1995). Also, in IsiXhosa (Nguni, Bantu), where there is complete reduplication of the base, word-initial onsetless syllables are not copied as part of the reduplicant (Cassimjee, 1994; Downing, 1998). This exclusion can be analysed as the effect of an onset condition on syllables in the domain relevant for these phonological processes (McCarthy \& Prince, 1993a; Downing, 1998).

Since constraints govern domain boundaries and domains determine the applicability of constraints, there can be interesting interactions between constraints such as the onset condition and those that govern harmony (Downing, 1999; Orie \& Pulleyblank, 2002). This interaction can result in misaligning the edges of a morphosyntactic constituent with the domain of the phonological constraints (Inkelas, 1989; Downing, 1999) or triggering a phonological operation (Orie \& Pulleyblank, 2002; Pulleyblank, 2004; Mudzingwa, 2010).

The disharmony of the onsetless prefixes in Fungwa points to an onset condition on the domain of harmony. To understand the requirement of this condition, its domain of operation and its interaction with the constraints on harmony, it is important to refer to general patterns governing the structure of words in Fungwa. To this end, the syllable structure of 634 lexical morphemes from my Fungwa corpus is observed. The 634 lexical morphemes can be grouped into five types based on the number and types of syllables.

\begin{tabular}{c|ccccc}
\hline$\sigma$ & cv & cv.cv & cv.cv.cv & cv.cv.cv.cv & v.cv.cv \\
\hline counts & 58 & 443 & 113 & 18 & 2 \\
\hline $\boldsymbol{\%}$ & $9.15 \%$ & $69.87 \%$ & $17.82 \%$ & $2.83 \%$ & $0.32 \%$ \\
\hline
\end{tabular}

Table 1: Syllable structure of 634 lexical morphemes

Table 1 shows all lexical morphemes in Fungwa are onsetful and a greater percentage (i.e 69.87\%) of the items is bisyllabic. The two onsetless lexical morphemes, [ع́lédè] 'pig' and [ágógó] 'gong', seem like loanwords as they are found in Nigerian languages which are unrelated (e.g Hausa) or at best distantly related (e.g. Yorùbá) to Fungwa. Based on this, the two words are considered exceptions.

That native Fungwa roots only contain onsetful syllables and that the roots are dominantly bisyllabic suggests that syllables must have onsets and that words are preferably bisyllabic. In this section, I only focus on the onsetfulness of syllables in Fungwa. The onsetfulness of all lexical morphemes in Fungwa suggests the existence of an onset condition. Note however that since all lexical morphemes are onsetful but function morphemes such as the prefixes may be onsetless, the lexical morphemes might be assumed as the domain of the onset condition (as in Mudzingwa, 2010). However, since function morphemes with onsets occur in the domain of harmony but onsetless ones do not, the domain of the onset condition must include both lexical and function morphemes. Alternatively, that vowel harmony requires the targets of harmony to be onsetful suggests the domain of the onset condition and vowel harmony coincide. In other words, PWd must be the 
domain of the onset condition in Fungwa as it is the assumed domain of vowel harmony.

To account for the disharmony of onsetless prefixes in Fungwa, the onset condition in PWd is formulated as in (10). This constraint requires that a syllable in PWd begin with an onset. In order to account for the onsetless prefixes occurring or being parsed outside PWd, I assume the strict layering hypothesis that a prosodic structure representation is strictly arranged according to the ordered set of categories in the prosodic hierarchy (see Nespor \& Vogel, 1986; Inkelas, 1989; Selkirk, 1995, 2011). The constraint on strict layering is formulated as in (11). This constraint requires a syllable to be parsed by PWd.

$\operatorname{ONSET}_{(\mathrm{PWd})}$ (Ito \& Mester, 2009)

A syllable in a prosodic word must begin with an onset.

Parse $\sigma$-PWd (McCarthy \& Prince, 1993a,b)

Every syllable must be parsed by PWd.

DEP (McCarthy \& Prince, 1995)

Every segment of the output has a correspondent in the input.

As illustrated in (13), an onsetless prefix would violate $\operatorname{ONSET}_{(\mathrm{PWd})}$ if integrated into a PWd (13-a) or if allowed to form a PWd on its own (13-b). However, ONSET $_{(\mathrm{PWd})}$ can be satisfied if the onsetless prefix is misaligned with the PWd (13-c). The structure in (13-c) suggests the onsetless prefixes in Fungwa satisfy $\mathrm{ONSET}_{(\mathrm{PWd})}$ through a misalignment with the PWd, the domain of harmony. In this case, the onsetless prefixes are prosodified as part of the prosodic phrase (PPhrase) (Nespor \& Vogel, 1986; Inkelas, 1993). The disharmony of onsetless prefixes can be interpreted as a byproduct of the prosodic misalignment. Prosodifying the onsetless prefix in a prosodic phrase results in the violation of the strict layering. The implication is that the constraint on onsetfulness outranks the strict layering in Fungwa.

$$
\text { /í-dógù// 'meat' }
$$

(a.)

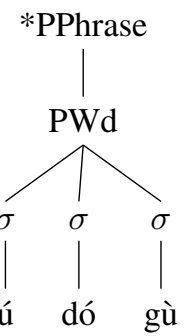

(b.)

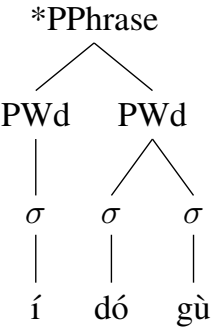

(c.)

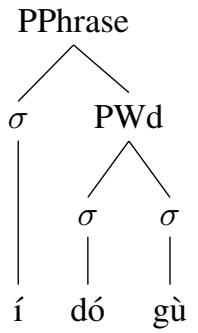

With $\operatorname{ONSET}_{(\mathrm{PWd})}$ forcing the misalignment of onsetless prefixes with the domain of harmony, I incorporate $\operatorname{ONSET}_{(\mathrm{PWd})}$ into the previous set of constraints on harmony. Since Fungwa does not resolve onset violations by epenthesis, I assume DEP (12) is high-ranked. In addition, the edges of a PWd are indicated with square brackets. Incorporating the onset condition on PWd into the constraints on harmony predicts the correct output for the onsetless prefix in (14).

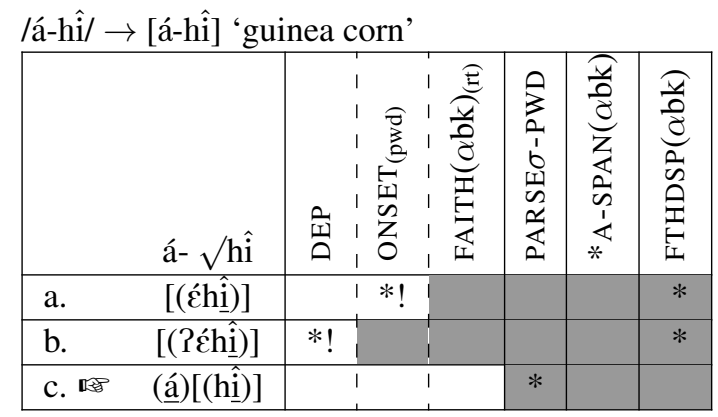

For the candidates in (14), ONSET $_{(\mathrm{PWd})}$ can only be satisfied by misaligning the onsetless prefix with the PWd. The language prefers prosodic misalignment of an onsetless prefix over an epenthetic onset that would satisfy $\mathrm{ONSET}_{(\mathrm{PWd})}$. This is illustrated in (14-b) where the candidate is ruled out despite satisfying the onset 
condition by virtue of an epenthetic consonant. Even though Fungwa does not allow the onset condition to be satisfied by vowel deletion or by consonant epenthesis, we could imagine a case where the morphology would place a vowel-initial prefix after another prefix (15). So far, my investigation of the language has not turned up any examples of this type.

\section{V- prefix following a CV syllable: /CV- V- CV/}

Based on the data collected so far, therefore, the onsetless prefixes are prosodically misaligned with the PWd, in order to satisfy the onset requirement on syllables within the PWd. The disharmony of these vowelintial prefixes is as a result of this misalignment with the domain of harmony. In other words, vowel harmony is a diagnosis for PWd boundaries.

4.2 Prosodic integration of $C V$ prefixes The analysis of the onsetless prefixes in Fungwa reveals that they are misaligned with the domain of harmony. This raises a question concerning the motivation for the integration of onsetful prefixes into a PWd, the domain of harmony. In other words, why are CV prefixes not also misaligned with the domain of harmony?

To understand the motivation for the integration of consonantial-initial prefixes into the domain of harmony, it is important to refer to the structure of words in Fungwa. As shown in the previous section, words in Fungwa are mostly bisyllabic, in addition to being onsetful. The high frequency of bisyllabic words in Fungwa is interpreted here as a preference for a bisyllabic word. This preference for bisyllabic word is formulated as the constraint in (16) which requires PWd to be minimally bisyllabic.

Minimality (Downing, 1999)

PWord can be no smaller than 2 syllables.

Considering (16), a monosyllabic root morpheme and a CV prefix would violate Minimality if they both form separate PWds. On the other hand, misaligning the CV prefix with PWd results in a violation of Minimality by the monosyllabic root morpheme and a violation of Parse $\sigma$-PWd by the CV prefix. Integrating the CV prefix into the same PWd with the monosyllabic root morpheme satisfies Minimality for both the prefix and the root morpheme. Given that the PWd is the domain of harmony, the vowel of the CV prefix will necessarily harmonise with the root vowel. In other words, the CV prefix is integrated into the domain of harmony as a result of Minimality and Parse $\sigma$-PWd. This analysis can also account for a CV prefix with a bisyllabic root since integrating the prefix into the prosodic word satisfies strict layering without producing any minimality violations.

Given that Minimality triggers the prosodic integration of the CV prefix into the domain of harmony, it is incorporated into the set of constraints on harmony. Minimality is ranked higher than *A-SPAN $(\alpha$ back $)$ being that prosodic integration entails harmony. However, it is not crucially ranked with respect to Parse $\sigma$-PWd. As illustrated in (17), prosodic integration accounts for a $\mathrm{CV}$ prefix occurring in the domain of harmony.

\begin{tabular}{|c|c|c|c|c|c|c|}
\hline & bi- $\sqrt{ }$ ?ô & 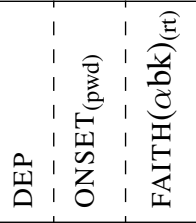 & 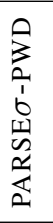 & $\begin{array}{l}1 \\
\vdots \\
\vdots \\
\vdots \\
\vdots \\
z \\
z\end{array}$ & 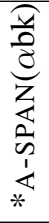 & 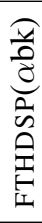 \\
\hline a. & [(bí)][(ใô)] & 1 & & $* ! *$ & & \\
\hline b. & [(bî́)(Pô̂)] & 1 & & & $* !$ & \\
\hline c. & {$[(\mathrm{b} \underline{1})(\mathrm{P} \underline{\hat{\mathrm{e}}})]$} & $* !$ & & & $*$ & $*$ \\
\hline d. & [(bílề)] & I $* !$ & & & & * \\
\hline e. & [(bú?ô̂)] & 1 & & & & * \\
\hline f. & (bî́)[(ㅇô)] & 1 & $* !$ & * & & \\
\hline
\end{tabular}

The ranking in (17) forces the prefix to occur in the same PWd as the root morpheme. For example in (17a), the monosyllabic root and the CV prefix satisfy *A-SPAN $(\alpha$ back) by forming PWds on their own, but the candidate is ruled out for violating Minimality. Despite satisfying Minimality by integrating the prefix 
and the monosyllabic root into the same PWd, the candidate in (17-b) is ruled out for a violation of *ASPAN $(\alpha$ back). Prosodic integration resulting in harmony is aptly illustrated in the winning candidate. With the winning candidate in (17-e), the CV prefix is integrated into a PWd with the root. Consequently, the vowel of the prefix agrees in the [back] feature value with the root vowel. Satisfying Minimality to the detriment of Parse $\sigma$-PWd rules out the candidates in (17-f).

To summarise, PARSE $\sigma$-PWd ensures that the CV prefixes are not misaligned with a PWd and Minimality triggers the integration of the CV prefixes into the domain of harmony. The vowel of the CV prefixes agreeing in backness with the root vowel is as a result of the prefixes occurring in a PWd with the root.

\section{Associative construction}

The associative construction in Fungwa is key to an understanding of the interaction between the constraint on harmony and the minimality condition. An associative construction in Fungwa structurally contains two noun phrases (NP) and a complementiser which occurs between the NPs. The first NP is the possessum and the second NP is the possessor. This is illustrated with the examples in (18). As illustrated with the associative construction in (18-a), the complementiser [nấ] occurs between [bà?à] 'child' and [vátù] 'person/man'. Furthermore, either the possessum or the possessor can be modified independently. Being able to modify the possessum or the possessum independently supports the analysis of the possessum and possessor as NPs.
Associative construction(AC)
a. bà?à nấ vátù
child.L C person
'the child of the man'
b. bà?à (lá) nắ vátú (lâ)
child.L DIST.DEM.AUG C person DIST.DEM.AUG
'that child of that man'

It is important to note that every tone bearing unit of the possessum bears L tone. For example, [bá?à] 'child' is realised as [bà?à] when it occurs as the possessum in (18). In the interlinear glosses of all associative constructions, L tone of the possessum is indicated. I assume [nấ] is a complementiser and occurs in the same constituent as the possessor. In the next section, I argue that harmony in the associative construction does not necessarily reflect the syntax, and must therefore be determined with respect to phonological constituents, not syntactic ones.

5.1 Complementiser in the associative construction The vowel of the complementiser undergoes backness harmony. Unlike the CV prefixes seen above, the vowel of the complementiser can harmonise with the vowel of the possessum or possessor in an associative construction when both the possessum and possessor stems have the same number of syllables. Consider the example sets below.
$\mathrm{NP}+\mathrm{C}+\mathrm{NP} \rightarrow$
NP.L C NP
Gloss

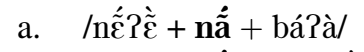
[nع̃̀? $1 \grave{\tilde{\varepsilon}}$ nấ=bá?à]
'the cow of a child'
/gع́pè + nấ + kókójồ/
[gèpè nấ=kókójồ]
'the cassava of a rooster'
b. /bá?à + nã́ + kélé?è/
/bá?à + nã́ + nếP
[bà?à=nấ kélé?è]
'the child of a sheep'
[bà?à=nấ nế? $\}$ है]
'the child of a cow'

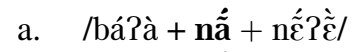
/báPà + nã́ + jíjè/
[bà?à n $\mathbf{\tilde { \varepsilon }}=n \varepsilon \tilde{R} P$ है]

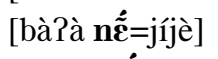
'the child of a cow'

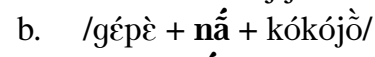

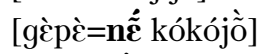
'the child of a goat'
/sćlè + nấ + dádà/
[sèlè=nen dádà]
'the cassava of a rooster'
'the money of father' 

a. /Rálà + nấ + bá?à/
[?àlà nẫ=bá\}à]
'the hand of a child'
/kókójồ + nấ + vátú/
[kòkòjồ nấ=vátù]
'the rooster of a man'
b. /Rínẽ̀ + nấ + sćlè/

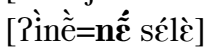
'the bank'
/sćlè + nấ + ?ínè̀/

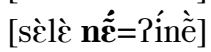
'the rent'

As shown in (19), the complementiser is [nấ] when the following or preceding root vowel is back, but it is [nế] when the following or preceding root vowel is front, as in (20). Similarly in (21), the complementiser is [nấ] between back root vowels, but [nع́⿱] between front root vowels. This freedom of direction frequently leads to free variation as in the second example in (19-b) and the first example in (20-a). This free variation is clearly illustrated with the complementiser occuring between two monosyllabic stems in (22).
$\mathrm{NP}+\mathrm{C}+\mathrm{NP} \rightarrow$
NP.L C NP
Gloss
a. $/ \mathrm{v} \hat{\varepsilon}+\mathbf{n a \tilde { a }}+? \hat{o} /$
[vè nấ=?ô]
'the finger of a woman'
b. $/ v \hat{\varepsilon}+\mathbf{n a \tilde { a }}+? \hat{o} /$

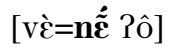
'the finger of a woman'

Simply put, the vowel of the complementiser can agree with the vowel of the possessum or the possessor when both the possessum and possessor are monosyllabic or bisyllabic.

The vowel of the complementiser agreeing with the preceding or the following stem vowel is typical of clitics (Zwicky \& Pullum, 1983; Marantz, 1988). Anderson (2005) describes this freedom of direction as promiscuity. Based on the promiscuous direction of the complementiser, I analyse the complementiser as a clitic. Regardless of the syntactic structure that is proposed for the associative construction in Fungwa, the vowel of the complementiser agreeing in either direction cannot be easily analysed syntactically. For instance, if the complementiser is analysed as either forming a constituent with the possessor or possessum, the vowel of the complementiser agreeing with either the vowel of the possessor or possessum still results in a mismtach between the syntactic constituent and the domain of harmony. In other words, the domain of harmony is nonisomorphic with any independently defined syntactic constituent in Fungwa. In prosodic structure theory (Selkirk, 1980, 1986, 2011), one of the arguments for prosodic constituents as the domain of phonological processes is the nonisomorphism between the relevant syntactic constituent and the corresponding phonological domain. This nonisomorphism supports the assumption that the PWd is the domain of harmony in Fungwa. Given that Minimality triggers the prosodic integration of the CV prefix into the domain of harmony, Minimality also triggers the integration of the complementiser into the preceding or the following domain of harmony. Consider the satisfaction of Minimality for the form in (23).

$$
\text { /dógù + nã́ + bélè/ }
$$

(a.)

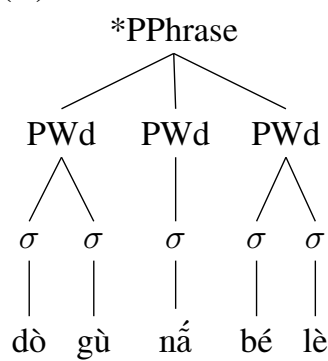

(b.)

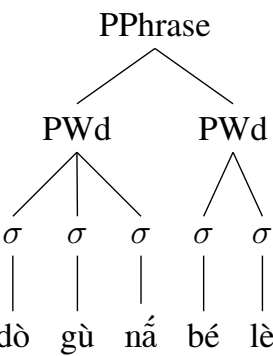

(c.)

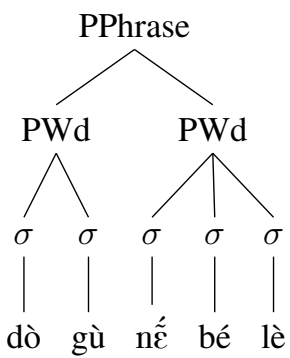

In (23-a), Minimality restricts the complementiser from forming PWd on its own. However, in (23-b) and (23-c), the complementiser satisfies Minimality when integrated into PWd with the preceding or the following root morpheme. Furthermore, the complementiser satisfying Minimality through prosodic integration with any of the roots also indirectly satisfies the strict layering (Selkirk, 1996, 2011). Similar to the vowels of the prefixes, the vowel of the complementiser agreeing in backness with the preceding or following stem vowel is an argument for prosodic integration. Using the previous set of constraints, this is illustrated in (24). 


\begin{tabular}{|c|c|c|c|c|c|}
\hline & $\sqrt{ }$ dógù nấ $\sqrt{ }$ bélè & 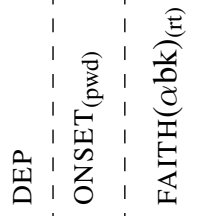 & 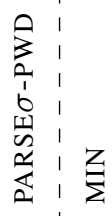 & 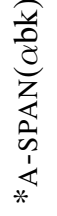 & 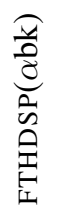 \\
\hline a. & [(dògù)] [(nấ)] [(bélè) $]$ & 1 & $* !$ & & $* *$ \\
\hline b. & [(dògù)(nấ)] [(bélè)] & 1 & 1 & $* !$ & $* *$ \\
\hline c. & [(dògù)] [(nấbólò)] & $* ! *$ & & & $* * *$ \\
\hline d. & [(dògù)] [(nếbélè)] & 1 & & & $* * *$ \\
\hline e. & [(dògùnấ)] [(bélè)] & 1 & & & $* * *$ \\
\hline f. & [(dògù)] (nấ) [(bélè)] & 1 & $* !$ & & $* *$ \\
\hline
\end{tabular}

The form in (24) shows that the complementiser satisfies Minimality through a prosodic integration with the preceding or the following root. Minimality rules out the candidate in (24-a). Although the integration of the complementiser into a PWd with a root satisfies Minimality in (24-b), the candidate is ruled out for violating *A-SPAN( $\alpha$ back). The winning candidates in (24-d)-(24-e) satisfy Minimality and *A-SPAN $(\alpha$ back $)$ showing that the prosodic integration necessitates vowel harmony.

While the present set of constraints predicts the two possible surface forms, predicting the form a speaker chooses to produce between the two optimal candidates is a problem. Considering the hypothesis that PPhrase is sensitive to speech rate (Orie \& Pulleyblank, 2002), a possible determining factor could be pauses. For example, it might be the case that the complementiser agrees with the preceding stem if there is a pause after the complementiser or the following stem if the pause occurs before the complementiser. This line of inquiry is left for future research on Fungwa associative constructions ${ }^{2}$. For the present data, PARSE $\sigma$-PWd restricts the complementiser from not being parsed by PWd. Minimality restricts the complementiser from forming PWd on its own. Consequently, the complementiser is integrated into PWd with either the preceding or following bisyllabic noun.

5.2 Complementiser between mono- and bisyllabic roots The effect of the minimality constraint on vowel harmony can be clearly understood through consideration of the example set in (25), in which the complementiser occurs between a monosyllabic root and a bisyllabic root. Although the complementiser can attach in either direction with bisyllabic nouns, monosyllabic nouns force unidirectional attachment.
$\mathrm{NP}+\mathbf{C}+\mathrm{NP} \rightarrow$
NP.L C NP
a. vứ + nấ + késù

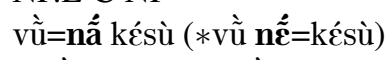
Gloss
dèní $+\mathbf{n} \mathbf{a}+k \hat{\tilde{a}}$

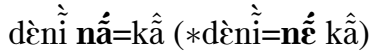
'the hole of buttock'
b. vátú + nấ $+\int \hat{\tilde{\varepsilon}}$
vàtù n $\mathbf{n}=\int \hat{\tilde{\varepsilon}}\left(* v a ̀ t u ̀=n a \tilde{~} \int \hat{\tilde{\varepsilon}}\right)$
'the fence of a killer'
về + nấ + bá?à

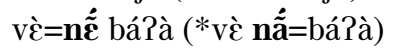
'a butcher'
'the finger of a child'

As shown in (25), the vowel of the complementiser obligatorily agrees in backness with the vowel of the monosyllabic root instead of the bisyllabic root. Consequently, the complementiser is [nấ] when the preceding or following vowel of the monosyllabic root is back, but [nế] when the preceding or following vowel of the monosyllabic root is front. This pattern of harmony is found for all the consultants, throughout the Fungwa corpus.

In sum, the vowel of the complementiser agrees in backness with the vowel of the preceding or following monosyllabic root instead of the bisyllabic root.

As shown earlier, Minimality requires the PWd in Fungwa to be minimally bisyllabic. Syllable size determining the trigger of harmony in Fungwa is another argument for imposing a minimality constraint on the domain of harmony. This can be argued by considering the form in (26).

\footnotetext{
2 Presumably, we could also predict the form that the speakers would choose to produce between these two candidates by reference to weighted constraints (cf. Pater, 2009) or crucially unranked constraints (cf. Boersma \& Hayes, 2001).
} 


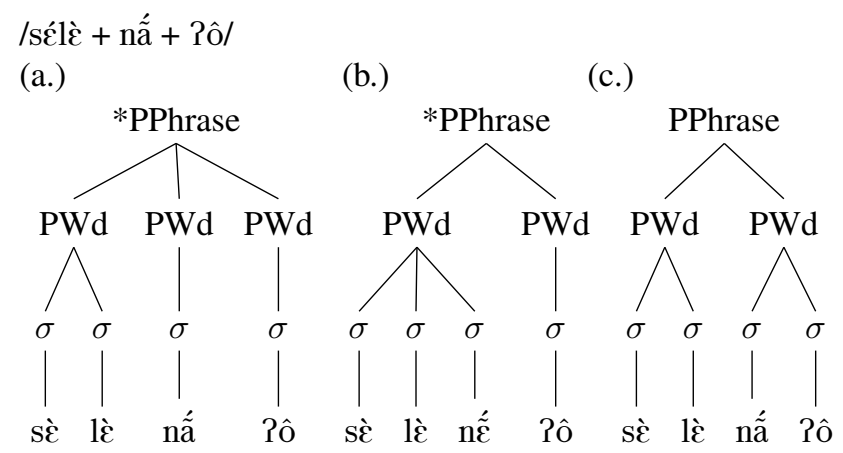

For the form in (26), if the complementiser and the monosyllabic root morpheme separately form PWds on their owns (26-a), they incur a violation each for Minimality. Also, if the complementiser is integrated into a PWd with the bisyllabic root (26-b), only the monosyllabic root violates Minimality. However, integrating the complementiser into a PWd with the monosyllabic root results in satisfying of Minimality for both the monosyllabic root and the complementiser. Consequently, the vowel of the complementiser only agrees in backness with the vowel of the monosyllabic root. With Minimality, the previous set of constraints accounts for the vowel of the complementiser agreeing in backness with a monosyllabic root and not with a bisyllabic root.

\begin{tabular}{|c|c|c|c|c|c|c|}
\hline$\sqrt{ }$ sélè nã́ $\sqrt{ }$ Pô & 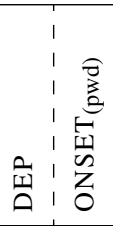 & 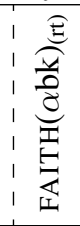 & 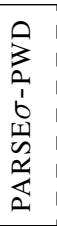 & Z & 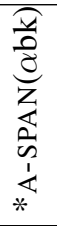 & 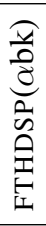 \\
\hline$[(\mathrm{s} \underline{\varepsilon} \mathrm{l} l \grave{\varepsilon})][(\mathrm{n} \underline{\mathrm{a}})][(\mathrm{P} \underline{\hat{o}})]$ & 1 & 1 & & $* ! *$ & & \\
\hline$[(\mathrm{s} \underline{\varepsilon} l \grave{\varepsilon})(\mathrm{n} \underline{\hat{a}})(\mathrm{P} \underline{\hat{o}})]$ & 1 & 1 & 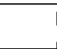 & & $* ! *$ & \\
\hline 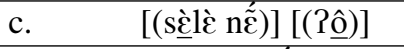 & 1 & 1 & & $* !$ & & $*$ \\
\hline 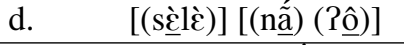 & 1 & 1 & 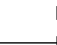 & & $* !$ & \\
\hline 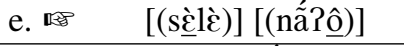 & i & 1 & 1 & & & $*$ \\
\hline f. $\quad[(\mathrm{s} \underline{\hat{\varepsilon}} \mathrm{l} \grave{\varepsilon})](\mathrm{n} \underline{\tilde{a}})[($ ? $\underline{\hat{o}})]$ & I & 1 & $* !$ & & & \\
\hline
\end{tabular}

The ranking in (27) only allowed a complementiser which is prosodically integrated into a PWd with a monosyllabic root. The candidate in (27-a) violate Minimality as a result of the complementiser and the monosyllabic root forming PWds on their own. Though integrating the complementiser into the same PWd with the monosyllabic root satisfies Minimality for the candidate in (27-d), this candidate is ruled out for violating Parse $\sigma-\mathrm{PWd}$. This is the same case with the candidate in (27-b). Meanwhile, the winning candidate in (27-e) satisfies Minimality and Parse $\sigma$-PWd, demonstrating that prosodic integration results in harmony.

To summarise, for a monosyllabic root to satisfy Minimality, the complementiser is prosodically integrated into a PWd with the monosyllabic root. Consequently, the vowel of the complementiser only harmonises with the monosyllabic root when the complementiser occurs between a monosyllabic root and a bi-/multi-syllabic root.

\section{Summary and conclusion}

I have described and analysed vowel harmony in Fungwa where (i) vowels of CV clitics and prefixes harmonise in [ $\alpha$ back] feature with an adjacent root vowel, but (ii) V prefixes do not harmonise. In the analysis presented here, the domain of harmony is the PWd which is also the domain of the minimality and onset conditions. While the minimality condition requires a PWd to be minimally bisyllabic (McCarthy \& Prince, 1993a, 1990), the onset condition (Ito \& Mester, 2009) requires a syllable in PWd to be onsetful.

To satisfy the minimality condition, CV prefixes and clitics are obligatory integrated into a PWd with a stem. The PWd also being the domain of harmony, the vowels of these CV clitics and prefixes harmonise with 
the stem vowel. Due to the requirement of onset condition within the PWd, onsetless prefixes are prosodically misaligned with the PWd. As a result of this misalignment with the PWd, these onsetless prefixes do not undergo harmony. Furthermore, backness harmony is accounted for with *A-SPAN $(\alpha$ back $)$ which operates in PWd; that the root vowel determines the harmonic feature is accounted for with a positional faithfulness constraint.

As argued here, backness harmony in Fungwa motivates an interaction between minimality, a condition on onsets, and vowel harmony. Similar to Fungwa, root-controlled harmony often targets clitics and affixes which are prosodically ill-formed (i.e monosyllabic) crosslinguistically (Akan (Clements, 1985); Turkish (Kirchner, 1993); Hungarian (Ringen \& Vago, 1998); etc.). The disharmonic onsetless prefixes in Fungwa are comparable to those of some Nilotic languages (Dimmendaal, 2002; Noonan, 1992). Research on such languages should investigate the effect of minimality and syllable-based conditions on the domain of harmony.

To conclude, the minimality condition, the onset condition and the constraint on vowel harmony refer to PWd as their domain of operation in Fungwa. Within this domain, these three constraint types interact. This interaction involves the integration of CV prefixes and clitics into the domain of harmony and the misalignment of $\mathrm{V}$ prefixes with the domain of harmony.

\section{References}

Akinlabi, Akinbiyi (1985). Tonal underspecification and Yoruba tone. Dissertation, University of Ibadan.

Akinlabi, Akinbiyi (2009). Neutral vowels in Lokaa harmony. Canadian Journal of Linguistics/Revue Canadienne de Linguistique 54:2, 197-228.

Anderson, Stephen (2005). Aspects of the theory of clitics. Oxford University Press, Oxford.

Baković, Eric (2000). Harmony, dominance, and control. Dissertation, Rutgers University.

Baković, Eric (2003). Vowel harmony and stem identity. San Diego Linguistic Papers 1, 1-42.

Boersma, Paul \& Bruce Hayes (2001). Empirical tests of the gradual learning algorithm. Linguistic Inquiry 32:1, 45-86.

Booij, Geert (1996). Cliticization as prosodic integration: The case of Dutch. The Linguistic Review 13:3-4, $219-242$.

Cassimjee, Farida (1994). IsiXhosa tonology. Manuscript, University of Illinois.

Clements, George N (1985). Akan vowel harmony: A non-linear analysis. Goyvaerts, Didier L (ed.), African Linguistics: Essays in Memory of MWK Semikenke, John Benjamins Publishing Company, Amsterdam/Philadelphia, 55-98.

Dimmendaal, Gerrit J (2002). Constraining disharmony in Nilotic: What does an optimal system look like? Journal of African Languages and Linguistics 23:2, 153-182.

Downing, Laura J (1998). On the prosodic misalignment of onsetless syllables. Natural Language \& Linguistic Theory $16: 1,1-52$.

Downing, Laura J (1999). Prosodic stem $\neq$ prosodic word in Bantu. Hall, T Alan \& Ursula Kleinhenz (eds.), Studies on the phonological word, John Benjamins Publishing Company, Amsterdam/Philadephia, vol. 174, 73-98.

Hall, Tracy Alan (1999). The phonological word: A review. Hall, Tracy Alan \& Ursula Kleinhenz (eds.), Studies on the phonological word, John Benjamins Publishing Company, Amsterdam/Philadephia, vol. 174, 1-22.

Inkelas, Sharon (1989). Prosodic Constituency in the Lexicon. Dissertation, Stanford.

Inkelas, Sharon (1993). Deriving Cyclicity. Hargus, Sharon \& Ellen M Kaisse (eds.), Phonetics and Phonology: Studies in Lexical Phonology, Academic Press, San Diego, vol. 4, 75-100.

Ito, Junko \& Armin Mester (2009). The onset of the prosodic word. Parker, Steve (ed.), Phonological argumentation: Essays on evidence and motivation, Equinox, London, 227-260.

Katamba, Francis (2003). Bantu nominal morphology. Nurse, Derek \& Gérard Philippson (eds.), The Bantu languages, Routledge, London \& New York, 103-120.

Kirchner, Robert (1993). Turkish vowel harmony and disharmony: An optimality theoretic account. Rutgers Optimality Workshop I 22, 1-20.

Marantz, Alec (1988). Clitics, morphological merger, and the mapping to phonological structure. Hammond, Michael \& Michael Noonan (eds.), Theoretical Morphology, Academic Press, San Diego, 253-270.

McCarthy, John (2004). Headed spans and autosegmental spreading. Manuscript, University of Massachusetts.

McCarthy, John \& Alan Prince (1990). Foot and word in prosodic morphology: The Arabic broken plural. Natural Language \& Linguistic Theory 8:2, 209-283.

McCarthy, John \& Alan Prince (1993a). Generalized Alignment. Booij, Geert \& Jaap van Marle (eds.), Yearbook of Morphology, Kluwer, Dordrecht, 79-153.

McCarthy, John \& Alan Prince (1993b). Prosodic morphology: Constraint interaction and satisfaction. Manuscript, University of Massachusetts.

McCarthy, John \& Alan Prince (1995). Faithfulness and reduplicative identity. Beckman, Jill N, Laura Walsh Dickey \& Suzanne Urbanczyk (eds.), Papers in Optimality Theory, GLSA, 249-384. 
McCarthy, John \& Alan Prince (1999). Faithfulness and identity in prosodic morphology. Fikkert, Paula \& Jacobs Haike (eds.), The prosody-morphology interface, Cambridge: Cambridge University Press, 218-309.

Mudzingwa, Calisto (2010). Shona morphophonemics: Repair strategies in Karanga and Zezuru. Dissertation, University of British Columbia.

Nespor, Marina \& Irene Vogel (1986). Prosodic Phonology. Foris, Dordrecht.

Noonan, Michael (1992). A grammar of Lango. Walter de Gruyter.

O'Keefe, Michael (2007). Transparency in Span Theory. Bateman, Leah, Michael O'Keefe, Reilly Ehren \& Adam Werle (eds.), Papers in Optimality Theory III, BookSurge Publishing, Charleston, South Carolina, 239-258.

Ola, Olanikẹ Ola (1995). Optimality in Benue-Congo prosodic phonology and morphology. Dissertation, University of British Columbia.

Orie, Olanike Ola \& Douglas Pulleyblank (2002). Yoruba vowel elision: Minimality effects. Natural Language \& Linguistic Theory 20:1, 101-156.

Padgett, Jaye (1997). Partial class behavior and nasal place assimilation. Suzuki, K \& D Elzinga (eds.), Proceedings of the Southwest Optimality Theory Workshop, University of Arizona, Tucson, 1-40.

Pater, Joe (2009). Weighted constraints in generative linguistics. Cognitive Science 33:6, 999-1035.

Peperkamp, Sharon (1999). Prosodic words. GLOT International 4, 15-16.

Pulleyblank, Douglas (1986). Tone in lexical phonology. D. Reidel Publishing Company, Dordrecht, Holland.

Pulleyblank, Douglas (2004). A note on tonal markedness in Yoruba. Phonology 21:3, 409-425.

Ringen, Catherine \& Robert Vago (1998). Hungarian vowel harmony in Optimality Theory. Phonology 15:3, $393-416$.

Selkirk, Elisabeth (1980). The role of prosodic categories in English word stress. Linguistic Inquiry 11:3, 563-605.

Selkirk, Elisabeth (1986). On derived domains in sentence phonology. Phonology 3:1, 371-405.

Selkirk, Elisabeth (1995). Surface restrictions in the distribution of lexical contrasts: The role for root faithfulness. Handout of a talk presented in LING 751, University of Massachusetts, Amherst.

Selkirk, Elisabeth (1996). The prosodic structure of function words. Morgan, James L \& Katherine Demuth (eds.), Signal to syntax: Bootstrapping from speech to grammar in early acquisition, Lawrence Erlbaum Associates, Mahwah, NJ, 187-214.

Selkirk, Elisabeth (2011). The syntax-phonology interface. Goldsmith, John A, Jason Riggle \& Alan C L Yu (eds.), The Handbook of Phonological Theory, Wiley-Blackwell, Malden, MA, vol. 2, 435-483.

Zwicky, Arnold \& Geoffrey Pullum (1983). Cliticization vs. Inflection: English n’t. Language 59:3, 502-513. 